\title{
O pequeno herói, Dostoiévski e Rimbaud
}

\begin{abstract}
Há uma passagem em $O$ pequeno heró $i,{ }^{2}$ de Dostoiévski, na qual o protagonista tem sua profunda devoção por Madame $M^{*}$ exposta e ridicularizada aos olhos de todos os presentes. "Sufocando de vergonha", ele dá um passo à frente e protesta; então, incontinente, "prestes a enlouquecer de horror, e, queimando como pólvora", precipitase para fora do salão e tranca-se no quarto, onde, a cara no travesseiro, permanece "surdo e impassível, como só um menino de onze anos é capaz".

Ele acaba de ser ferido no ponto mais sensível de sua existência: o amor que sente por Madame $\mathrm{M}^{*}$ é também o motor que irriga a consciência de si e de sua própria dignidade. Tudo isso, até então protegido dos olhos do público por um sentimento de pudor, acaba de ser "destroçado, aniquilado".

Era a primeira vez na vida que experimentava uma dor grave, o ultraje e a ofensa. [...] Eu, uma criança, tivera um primeiro sentimento, ainda vago e inexperiente, grosseiramente ultrajado, tivera meu primeiro sentimento de pudor fragrante e virginal tão cedo exposto e profanado, e minha primeira impressão estética, talvez muito séria, ridicularizada.
\end{abstract}

Alberto Martins

Dando um salto, acredito que é uma percepção de natureza muito semelhante que está por trás da formulação de Rimbaud - “A última inocência e a última timidez" , no quarto fragmento da Temporada no inferno. A personagem de Dostoiévski terá duas oportunidades para reparar a ofensa, resgatar a dignidade e recompor de certo modo o equilíbrio do mundo: a primeira, em público, quando cavalga o garanhão impetuoso e é aclamado "um cavaleiro, um herói”; a segunda, no jardim, na intimidade

\footnotetext{
${ }^{1}$ Alberto Martins é escritor e artista plástico. Publicou, entre outros, os livros de poemas Cais (2002) e Em trânsito (2010); e as ficções A história dos ossos (2005) e Livia e o cemitério africano (2013, prêmio APCA de Melhor Romance do ano). Trabalha como editor em São Paulo.

${ }^{2}$ Escrita entre julho e dezembro de 1849 , a novela só seria publicada em agosto de 1857. Os trechos citados foram extraídos da tradução de Fátima Bianchi, O pequeno herói (São Paulo, Editora 34, 2015).
} 
velada com o alvo de sua devoção, quando devolve "anonimamente" a Madame $\mathbf{M}^{*}$ a carta comprometedora.

Para Rimbaud, porém, o gesto de heroísmo galante não é mais historicamente possível; portanto, não é o caso de restaurar o equilíbrio do mundo, mas sim de transtorná-lo. (“Agora emprego as minhas forças para me tornar o mais crápula possível." "Imagine um homem implantando e cultivando verrugas no rosto." "Trata-se de tornar a alma monstruosa." "[o poeta] esgota em si mesmo todos os venenos." "Tua memória e teus sentidos serão apenas o alimento de teu impulso criador. Quanto ao mundo, quando tiveres partido, no que terá se transformado? Em todo caso, nada das aparências atuais. ${ }^{\prime 3}$ Etc. Etc. Etc.)

Dostoiévski compreendeu isso e, a partir das Memórias do subsolo ("Sou um homem doente... Um homem mau. Um homem desagradável.”), ${ }^{4}$ também se converteria num grande especialista em venenos.

\footnotetext{
${ }^{3}$ Verti, com alguma liberdade, passagens de Rimbaud extraídas da carta a Paul Demeny (15 de maio de 1871) e da Temporada no inferno (1873).

${ }^{4}$ A fala inicial do narrador das Memórias do subsolo é da tradução de Boris Schnaiderman (São Paulo, Editora 34, 2000).
} 